\title{
Mass balance and recession of Ürümqi glacier No. 1, Tien Shan, China, over the last 45 years
}

\author{
JING Zhefan, ${ }^{1,2}$ JIAO Keqin, ${ }^{1}$ YAO Tandong, ${ }^{1,2}$ WANG Ninglian, ${ }^{1,2}$ LI Zhongqin ${ }^{1}$ \\ ${ }^{1}$ Key Laboratory of Cryosphere and Environment, Cold and Arid Regions Environmental and Engineering Research Institute, \\ Chinese Academy of Sciences, 260 Donggang West Road, Lanzhou 730000, China \\ E-mail: jingzf@Izb.ac.cn \\ ${ }^{2}$ Institute of Tibetan Plateau Research, Chinese Academy of Sciences, Beijing 100085, China
}

\begin{abstract}
Observations of Ürümqi glacier No. 1 at the headwaters of the Ürümqi river, Tien Shan, show remarkable changes between 1959 and 2003. The cumulative mass balance of the glacier is $-10032 \mathrm{~mm}$, equivalent to $11.1 \mathrm{~m}$ of glacier ice, or $20 \%$ of the glacier volume, showing particular sensitivity to temperature change. The speed of glacier flow has gradually declined, especially since the 1980s. From 1980 to 2003, the flow speed of the east and west branches of the glacier decreased by about $21 \%$ and $43 \%$, respectively. The glacier continuously retreated from 1962 to 2003 . Its length has decreased by about $180 \mathrm{~m}(7.5 \%)$ and its area has diminished by $0.23 \mathrm{~km}^{2}(11.8 \%)$. Analyses show that summer precipitation is negatively correlated with mass balance and positively associated with runoff. These relationships are reasonable, as higher precipitation leads to higher runoff and lower glacier melt. On the other hand, summer temperature is negatively correlated with mass balance and positively associated with runoff, as higher temperatures lead to higher glacier melt and thus higher runoff, with summer temperatures controlling mass-balance variation. Over the past 45 years the negative mass balance, caused by higher ablation than accumulation, is associated with precipitation increase and temperature warming over the study area.
\end{abstract}

\section{INTRODUCTION}

Annual or periodic changes in temperature and precipitation in glacial regions can be detected from mass-balance and snowline measurements. If there is a change in regional climate trend, evidence from glaciers may directly reflect adaptations to such climate changes. Previous research has shown that small glaciers are not only sensitive to climate

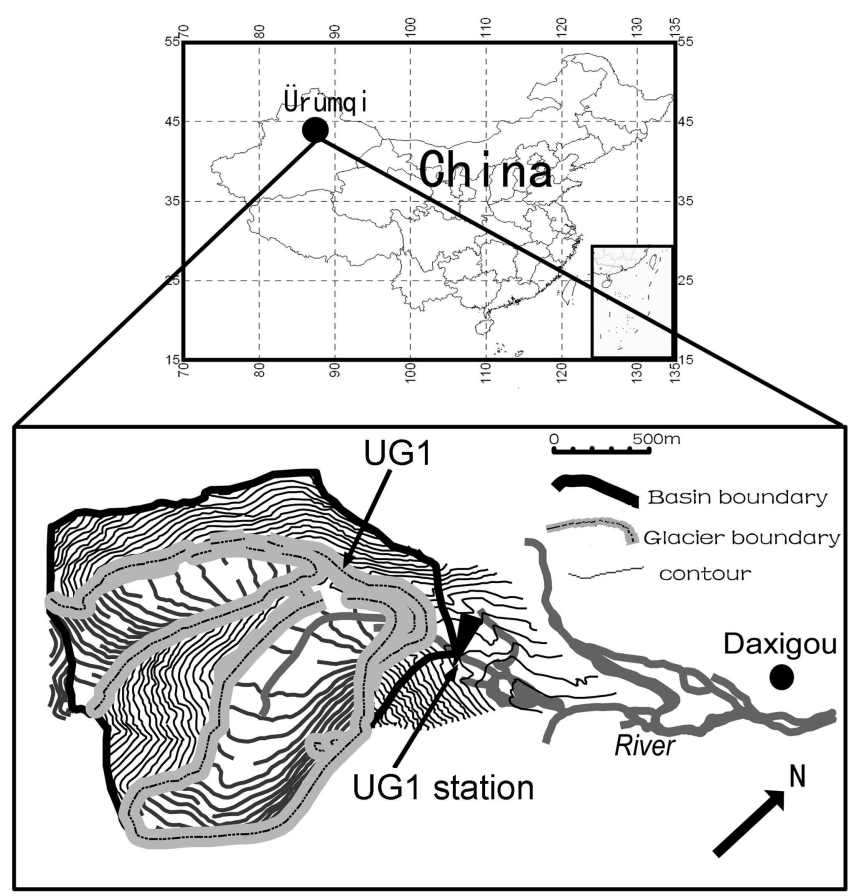

Fig. 1. Location of Ürümqi glacier No. 1 (UG1) and Daxigou meteorological station. change but are also easy to observe and study. Ürümqi glacier No. 1 (UG1) is located in the headwaters of the Ürümqi river $\left(43^{\circ} 05^{\prime} \mathrm{N}, 86^{\circ} 49^{\prime} \mathrm{E}\right)$, Tien Shan, about $120 \mathrm{~km}$ southeast of Ürümqi, China (Fig. 1). It has the longest monitoring record of any glacier in China, covering the period 1958-2003. It is a small valley glacier with two branches, east and west. Due to glacier retreat, these two branches became separated into two small independent glaciers in 1993. The length and area of the glacier have respectively decreased from 2.40 and $1.95 \mathrm{~km}^{2}$ in 1962 to 2.20 and $1.72 \mathrm{~km}^{2}$ in 2003 , with an elevation of 3740 $4486 \mathrm{~m}$ a.s.l. The average ice thickness determined from the radar measurement in the early 1980s is about $55 \mathrm{~m}$ (Zhang and others, 1985). Meteorological data have been collected since 1958 at the Daxigou meteorological station, located at 3540 m a.s.l., about $2 \mathrm{~km}$ downstream of UG1 (Fig. 1). The mean annual temperature and precipitation are $-5.1{ }^{\circ} \mathrm{C}$ and $450 \mathrm{~mm}$, respectively. The Tien Shan glaciological station has recorded glaciological observations from 1958 to the present day. UG1 has shown obvious changes in mass balance, equilibrium-line altitude (ELA), glacier dimensions (length, thickness, area and volume), flow speed etc., reflecting the response of this and other glaciers in the Tien Shan to climate change during the past 45 years.

\section{RECENT VARIATION OF ÜRÜMQI GLACIER NO. 1}

Glacier mass balance is an important index of a glacier's response to climate change. Climate change can lead to changes of glacial accumulation and ablation, and potentially influence the advance or retreat of the glacier terminus. Glacier mass balance has been calculated using contour maps of accumulation and ablation, data measured at a permanent stake network (about 50-80 stakes in nine to ten rows on the glacier) and additional snow pits (You and 


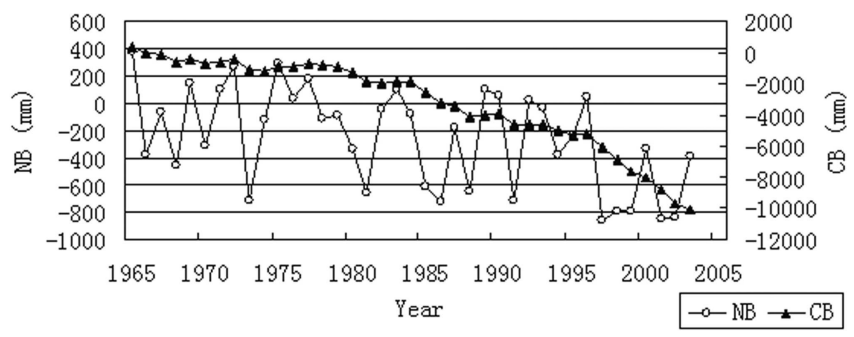

Fig. 2. Annual net mass balance (NB) and cumulative mass balance (CB) of UG1.

others, 1998; Li and others, 2003). The annual net accumulation, ablation and ELA have also been determined. The mass-balance data are available from 1959 to 2003. The glacier length and area have been determined using glacier maps from 1962, 1964, 1973, 1980, 1986, 1992, 1994, 2000 and 2002. The retreat of the glacier terminus is directly measured every year. The glacier ice thickness or glacier bed altitude was measured by radar and verified by borehole data in 1981 (Zhang and others, 1985). Annual mass balance varies between 375 and $860 \mathrm{~mm}$ during the period 1958-2003 (Xie and Ge, 1965; Zhang, 1981; Jiao and others, 2000; Tien Shan glaciological station, 2002; Li and others, 2003). Glacier mass balance has decreased in the last 45 years, especially in the most recent 25 years (Fig. 2). During the last 45 years, a negative mass balance has existed in 30 years and a positive mass balance in 15 years. During the 25 year period 1978-2003, a positive mass balance appears in only 5 years, and the mass loss of UG1 represents $86 \%$ of the total over the past 45 years, with $52 \%$ of this loss occurring in the last decade. The five years of most negative mass balance $(>790 \mathrm{~mm})$ all occurred after 1997 . The cumulative mass balance reached $-10032 \mathrm{~mm}$ over the study period, equivalent to a glacier thinning of $11.1 \mathrm{~m} \mathrm{(20 \%}$ of average glacier thickness).

The flow speed of the glacier has been measured since 1959. Triangular surveying was done with a theodolite before 1985, a range finder during the period 1986-95 and the global positioning system (GPS) from 1996. Data were also measured at the permanent stake network, enabling mass-balance calculations. The flow speed for 1960, 1961 and 1962 was $21.30,29.23$ and $31.48 \mathrm{~m} \mathrm{a}^{-1}$, respectively (Zhang, 1965). From August and September 1973 the flow speed of the glacier was measured (Wang and others, 1976) and it was calculated to be 5.48 and $10.32 \mathrm{~m} \mathrm{a}^{-1}$ for the east and west branches respectively (Huang and Sun, 1982). Since 1980, continuous and systematic observations of glacier flow speed have been performed. Due to the terrain and surface slope of the glacier, the west branch has a larger flow speed than the east branch (Fig. 3), and due to continued glacier shrinkage these two branches became separated into two small independent glaciers with a consequent sudden increase in flow speed in 1993. The speed of glacier flow is otherwise shown to be gradually decreasing, especially since 1994. The flow speed of the east and west branches of the glacier has decreased over the period $1980-2003$ by about $21 \%$ and $43 \%$, respectively. Such trends are completely consistent with trends in glacier mass balance. During the period 1958-2003, the mean glacier thickness decreased by $11.1 \mathrm{~m}$ (20\% of average glacier thickness). As we know, the flow speed of the ice surface is directly proportional to the glacier thickness, and a

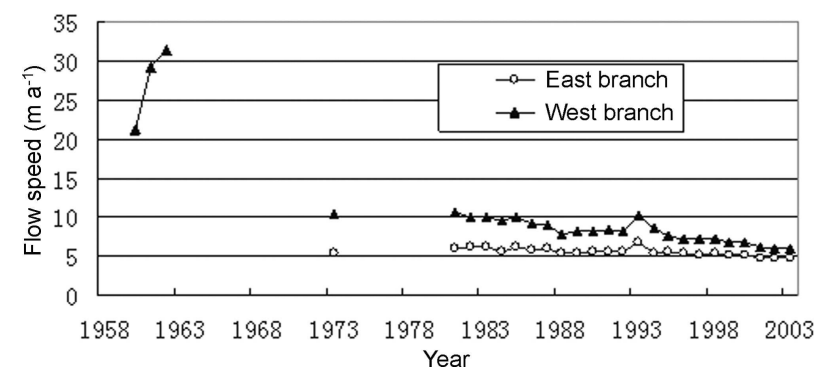

Fig. 3. Flow speed of UG1.

change in thickness will have a strong influence upon flow speed, so we can expect a corresponding decrease in glacier flow speed.

Since the 1960s, UG1 has been mapped nine times using large-scale cartography, table topography (1962), ground photography (1973, 1980, 1986 and 1994), air photography (1964 and 1992; Chen and others, 1996) and GPS (2000, 2002). Additionally, since 1980 the location of the glacier terminus has been measured every year, providing reliable proof of dimensional changes in the glacier. During the period 1962-2003 the glacier terminus retreated by $180.3 \mathrm{~m}(7.5 \%)$, with a mean retreat of $4.4 \mathrm{ma}^{-1}$ (Fig. 4). The retreat speed was $5.96 \mathrm{~m} \mathrm{a}^{-1}$ in $1963,3.33 \mathrm{~m} \mathrm{a}^{-1}$ in the $1970 \mathrm{~s}, 3.73 \mathrm{ma}^{-1}$ in the $1980 \mathrm{~s}$, and $4.61 \mathrm{ma}^{-1}$ in the 1990s. Figure 4 shows that the glacier has always been in retreat and that the retreat speed increased in the 1980s and 1990s. Due to the retreat of the glacier terminus, the east and west branches of the glacier separated completely to become two small glaciers in 1993. The retreat speed of the west branch terminus apparently quickens more than that of the east branch, for the following reasons: (1) the west branch is of smaller dimensions than the east branch, and so is more sensitive to climate change; (2) the area of the firn basin (accumulation area) of the west branch is smaller, i.e. the glacier accumulation is less; and (3) the underlying topography of the west branch terminus is an abrupt ice ridge, which causes the ice not only to thin, but also to break up more easily. Changes in glacier area can be calculated using a series of large-scale maps of UG1 (Fig. 5). The area of the glacier decreased by $0.23 \mathrm{~km}^{2}$ $(11.8 \%$ of the area in 1962) from 1962 to 2002. Furthermore, the mean ELA of the glacier is about $4056 \mathrm{~m}$ a.s.l. over the period 1958-2003. The ELA has moved up $37 \mathrm{~m}$ due to climate warming. This rise is most noticeable since 1997, when it is above 4050 ma.s.l., with a mean of $4110 \mathrm{~m}$ a.s.l.

The seasonal regime of monthly temperature and precipitation is shown in Figure 6 for the period 1958-2003. Monthly mean temperatures are -13 to $-16^{\circ} \mathrm{C}$ in winter

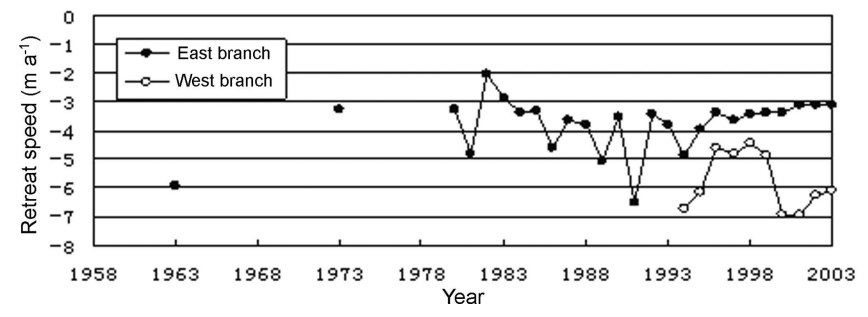

Fig. 4. Rate of retreat of the UG1 terminus. 


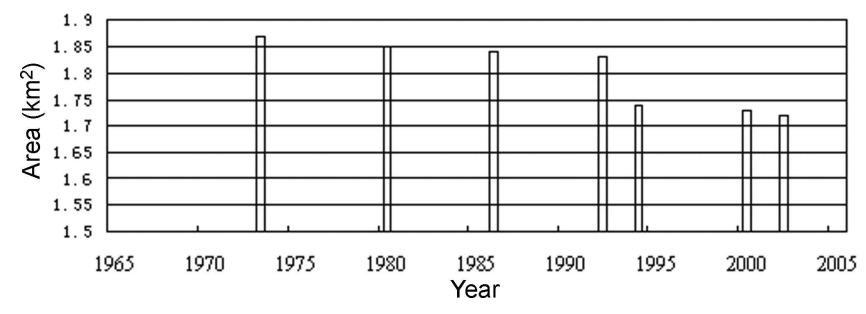

Fig. 5. Variation in area of UG1.

months (December-February) and $3-5^{\circ} \mathrm{C}$ in summer months (June-August). Trends in monthly temperature from February to May show an increase, and the warming trend in June, July, September and November is statistically significant at the $95 \%$ confidence level. However, March and April became slightly cooler by about $0.3-0.9^{\circ} \mathrm{C}$ over the study period. As a result of the warming in most months, annual mean temperature has increased by about $0.8^{\circ} \mathrm{C}$ over the last five decades. Temperature changes are particularly strong since 1997. For example, summer (June-August) mean temperatures are $3.0-4.6^{\circ} \mathrm{C}$ during the period $1958-96$, and $4.4-5.8^{\circ} \mathrm{C}$ since 1997 , indicating a step increase of $1.0^{\circ} \mathrm{C}$ since 1997 (Fig. 7). This corresponds with a cumulative mass-balance increase of $>400 \mathrm{~mm}$ since 1997 (Fig. 2), indicating that the glacier mass balance is sensitive to temperature change.

The monthly precipitation regime is also depicted in Figure 6. It shows that the monthly precipitation varies from 2 to $50 \mathrm{~mm}$ during the winter half of the year (SeptemberMay), whereas the summer months are relatively wet, with precipitation peaks of 97 and $118 \mathrm{~mm}$ in July and August, respectively. Snowfall dominates the type of precipitation, with only $17 \%$ of precipitation in the warmest month of July being rainfall. Statistically, annual total precipitation has increased significantly by $19 \%(87 \mathrm{~mm})$ over the last few decades. Annual precipitation has increased since 1987, along with the year-to-year variability. The difference in mean annual precipitation between the periods 1959-87 and $1988-2003$ is $76 \mathrm{~mm}$, or $17 \%$ of the entire record (Fig. 8). Summer precipitation is negatively correlated with mass balance and positively associated with runoff. These relationships, although very weak statistically, are reasonable, as higher precipitation leads to higher runoff and lower glacier melt (Yang and others, 1988; Liu and others, 1998). Similarly, summer temperature is negatively correlated with mass balance and positively associated with runoff, as higher temperatures lead to higher glacier melt and thus higher runoff.

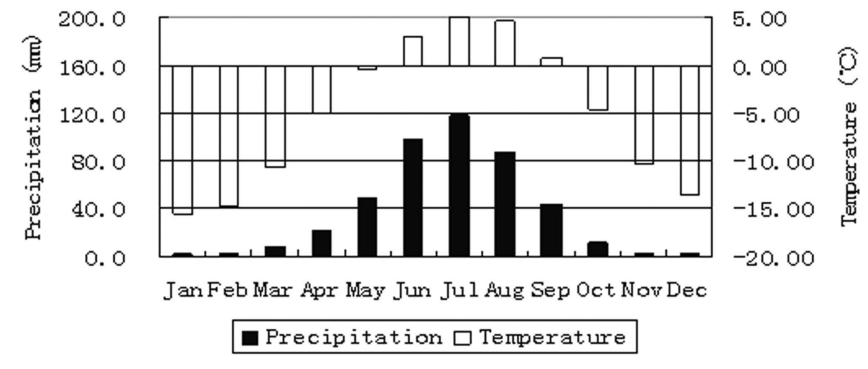

Fig. 6. Mean monthly temperature and precipitation at Daxigou station, 1958-2003.

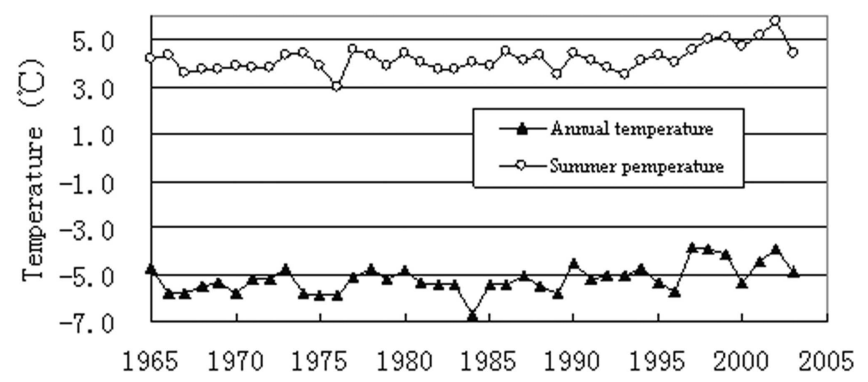

Fig. 7. Annual and summer air temperature at Daxigou station, 1958-2003.

\section{CONCLUSION}

This study has analyzed long-term climate and glacier records to determine glacier response to climate change over the past 45 years in the Ürümqi river. The cumulative mass balance is $-10032 \mathrm{~mm}$, equivalent to $11.1 \mathrm{~m}$ of glacier ice, or $20 \%$ of the glacier volume. The mass balance of UG1 has been shown to be sensitive to temperature change. The glacier flow speed has gradually decreased, especially since the 1980s. The flow speed of the east and west branches of the glacier decreased by about $21 \%$ and $43 \%$, respectively, from 1980 to 2003 . The glacier continuously retreated from 1962 to 2003 . Its length and area have decreased by about $180 \mathrm{~m}(7.5 \%)$ and $0.23 \mathrm{~km}^{2}(11.8 \%)$, respectively.

Summer precipitation is negatively correlated with mass balance and positively associated with runoff. These relationships are reasonable, as higher precipitation leads to higher runoff and lower glacier melt. On the other hand, summer temperature is negatively correlated with mass balance and positively associated with runoff, as higher temperatures lead to higher glacier melt and thus higher runoff. The summer temperature controls glacier mass-balance variation. It is important to note that, over the past 45 years, the negative mass balance, caused by higher ablation than accumulation, is associated with both a precipitation increase and temperature warming over the study area.

\section{ACKNOWLEDGEMENTS}

This research is supported by the Centurial Program (2004401) and the National Nature Science Foundation of China (90202013), the Innovation Research Project (KZCX3SW-339-3) of the Chinese Academy of Sciences, and the National Basic Research Program of China (2005CB422003). The manuscript was improved by suggestions from two anonymous reviewers. We thank P. Mayes for improving the English.

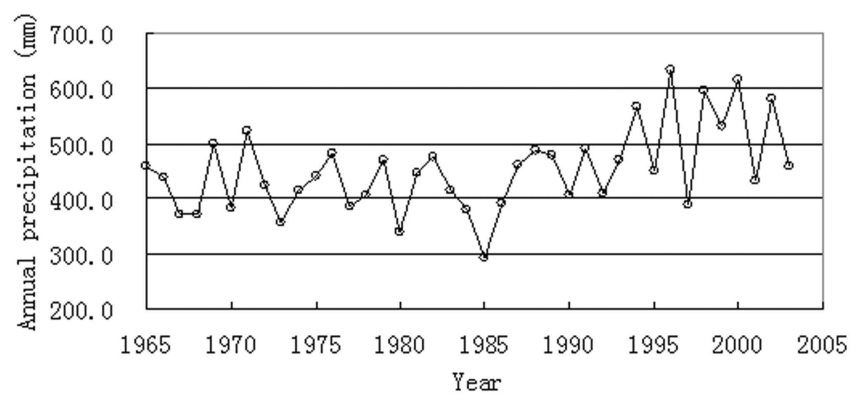

Fig. 8. Annual precipitation at Daxigou station, starting in 1960. 


\section{REFERENCES}

Chen, J., C. Liu and M. Jin. 1996. Application of the repeated aerial photogrammetry to monitoring glacier variation in the drainage area of the Ürümqi River. J. Glaciol. Geocryol., 18(4), 331-336. [In Chinese with English summary.]

Huang, M. and Z. Sun. 1982. Some flow characteristics of continental-type glaciers in China. J. Glaciol. Cryopedol., 4(2), 35-45. [In Chinese with English abstract.]

Jiao, K., C. Wang and T. Han. 2000. A strong negative mass balance recently appeared in the Glacier No. 1 at the headwaters of the Ürümqi River. J. Glaciol. Geocryol., 22(1), 62-64. [In Chinese with English summary.]

Li, Z., T. Han, Z. Jing, H. Yang and K. Jiao. 2003. A summary of 40year observed variation facts of climate and Glacier No. 1 at headwaters of Ürümqi River, Tianshan, China. J. Glaciol. Geocryol., 25(2), 117-123. [In Chinese.]

Liu, C., Z. Xie and M.B. Dyurgerov. 1998. Tianshan Glacier. Beijing, Science Press. [In Chinese.]

Sun, Z., Y. Chen, G. You and J. Han. 1985. Flow characteristics of Glacier No. 1 at the headwater of Ürümqi River, Tianshan. J. Glaciol. Geocryol., 7(1), 27-40. [In Chinese.]

Tien Shan glaciological station. 2002. Annual report of Tien Shan glaciological station. Lanzhou, Chinese Academy of Sciences. Lanzhou Institute of Glaciology and Geocryology. [In Chinese].

Wang, W., J. Liu, X. Luo and G. You. 1976. A retreat in the Glacier No. 1 at the headwaters of the Ürümqi River, Tianshan, at the 1962-1973 year and contrast survey of the movement. In Collected papers by Lanzhou Institute of Glaciology,
Geocryology and Desert, No. 1. Beijing, Science Press, 32-35. [In Chinese.]

Xie, Z. and G. Ge. 1965. Accumulation, ablation and mass balance of Glacier No. 1, headwaters of Ürümqi River Head, Tianshan Mts. In Study on glaciers and hydrology in Ürümqi River, Tianshan mountains. Beijing, Science Press, 24-34. [In Chinese.]

Yang, D., T. Jian, Y. Zhang and E. Kang. 1988. Analysis and correction of errors in precipitation measurement at the head of Ürümqi River, Tien Shan. J. Glaciol. Geocryol., 10(4), 384-399. [In Chinese with English abstract.]

You, G., Y. Shi, E. Kang and J. Chen. 1988. Map of Glacier No.1 and No.2 at the Ürümqi river, Tianshan. Scale 1:5,000. Xi'an, Xi'an Cartographic Publishing House. [In Chinese.]

Zhang, C. 1965. Calculated for the flow speed and thickness of Glacier No. 1 at the headwater of the Ürümqi River in the Tianshan Mountains. In Study on glaciers and hydrology in Ürümqi River, Tianshan mountains. Beijing, Science Press, 3851. [In Chinese.]

Zhang, J. 1981. Mass balance studies on the No.1 Glacier of Ürümqi river in Tianshan. J. Glaciol. Cryopedol., 3(2), 32-40. [In Chinese with English summary.]

Zhang, J., X. Wang and J. Li. 1984. Study on relationship between mass balance change of Glacier No. 1 at the headwaters of Ürümqi River, Tianshan and climate. J. Glaciol. Geocryol., 6(4), 25-36. [In Chinese with English summary.]

Zhang, J., G. Zhu, S. Qian, J. Chen and Y. Shen. 1985. Radar measuring ice thickness of glacier No. 1 at the source of Ürümqi River, Tianshan. J. Glaciol. Geocryol., 7(2), 153-162. [In Chinese with English abstract.] 